\title{
Impact of e-Content Integration in Science on the Learning of Students at Tertiary Level
}

\author{
S. Amutha
}

\begin{abstract}
In the present era of grey revolution, teachers' role is highly challenging to make their students meet global demands. Instructional practices and instructional strategies vary based on the need of the learners. Technology can be imperative for individualized instruction in order to bridge the gaps between teaching and learning. Contribution of science is instrumental for the economic growth and social transformation. The Kothari commission report asserts that if science is poorly taught and badly learnt, it is a little more than burdening the mind with dead information. It could even degenerate into new superstitions. In India, science teaching needs overhauling.

To understand the real concept of science, classical face-to-face teaching methods may have to be supplemented by innovative methods. Developing e-content is emerging to be an innovative method which could help the learners visualize the content so as to make them be creative and productive learners. The e-contents are developed with the integration of multimedia components such as text, audio, video, animation and image which are set to ensure better understanding of science by the students. In that way, e-content on cloning was developed for finding its impact on learners. 60 final year undergraduate Botany students from both genders were taken as a sample. Results revealed that e-content has its positive impact on science learning among students irrespective of gender.
\end{abstract}

Index Terms-Grey revolution, instructional practices, instructional strategies, e-contents.

\section{INTRODUCTION}

The primary objective of science education is to improve teaching and learning practices. The field of science education has developed into a diverse aggregation of interest areas as witnessed in the pages of research in science education [1] and other journals in this field. Complex science topics deal with complex systems that have multiple interconnected components, and whose behavior is not explained exclusively by examining the isolated components, since the phenomena result from the multiple interactions of the components [2]. In the 21 st century the undergraduates learn how to integrate concepts across levels of organization and complexity and to synthesize and analyze information that connects conceptual domains [3]. The New Zealand Council for Educational Research (NZCER) [4] report highlights the increasingly important observation that science education now has several distinct objectives.
As most parents think, the traditional role of science education is to provide children with the knowledge in physics, chemistry, biology and mathematics that will allow them to enter tertiary education in a domain where these knowledge and skills will be useful [5].

Comprehension of such topics in science occurs from the new understanding of the information by the learner. However, learners are not very successful in generating their own meaning, especially in computer based learning environments in which learners are required to make decisions about their learning process, since they rarely regulate their own learning process cognitively or metacognitively [6].

There are some underlying principles in explaining any process in science with different components. To understand the principles and process, learners need to integrate all properties and functions of each individual component. Mere memorization of the components of the system leads to little understanding of how the system works [7]. Indeed, e-Learning modules will provide multi-sensory experience to the learners. Also the learners will be able to visualize the entire content and attain mastery over the topics [8].

Multimedia tools provide a wide range of sensory stimuli. Remembering the famous quote, 'I hear and I forget, I see and I remember, I do and I understand', one can realize the need for technology integration in science education. The animations, simulations, software packages, speech, music, multimedia networks, image enhancements, etc. create virtual realities and experience for the learners, which in turn, help in making learning a more direct, useful, and joyful experience and in retaining knowledge for a longer time [9].

\section{OBJeCtives OF THE STUDY}

The aim of the research work is to assess the impact of e-content integration in science teaching on the learning performance of college students. The following objectives are to be accomplished:

- To develop and validate an e-content on cloning

- To find out the effectiveness of the e-content on cloning

- To develop an achievement test on cloning

- To determine the level of performance in pre-test and post-test

\section{RESEARCH QUESTIONS}

1) Can e-content in cloning be effective with students at Tertiary level?

2) Can the strategy make any gender difference?
Manuscript received December 25, 2014; revised March 4, 2015.

S. Amutha is with the Bharathidasan University of Tiruchirappalli, Tamil Nadu, India (e-mail: amuthapraveen@gmail.com). 


\section{DESIGN OF THE STUdY}

Experimental research method with a control design was adopted in this study. Investigator selected 60 undergraduate final year Botany students as a sample from colleges in Tiruchirappalli, India.

E-content on cloning was developed by the investigator. Based on the material incorporated in the e-content, an achievement test was developed on the basis of guidelines of Bloom [10] which was validated by the experts. The pre-test was conducted initially for 60 students. The students were divided into two groups viz. control and experimental group. Only experimental group was treated with e-content and classical approach was adopted for the control group. The investigator clarified their queries if any, raised by the students during the experimentation phase. Learners were provided a congenial atmosphere for the experimentation. Soon after the experiment was over, the post-test was conducted for all the 60 students.

\section{DEVElopMEnTAl Phase}

E-content is developed with the integration of multimedia components such as text, audio, video, animation and image which will give multi-sensory experience to the learners.

The following are the different steps to be adopted for the development of an e-content:

\section{SELECTION OF THE TOPIC}

Selection of the topic for the development of e-content has its own significance in any subject in general and science in particular. Unless a teacher provides opportunity for a student to visualize certain functions in science, the student finds very difficult to master the ideas behind those contents. Science involves explaining abstract concepts and often call for visualization of microscopic objects / organisms or gigantic processes. These challenges are met effectively by using graphics, animations and simulations on computers. Use of technology in classroom increases productivity so as to facilitate the instructional process. Indeed, technology is used to provide opportunities for students to apply the knowledge gained from active participation, exploration and adaptation in the real world.

Therefore the selection of the topic has to be done keeping the following principles in the mind:

- The topic should be relevant to the audience and it should conform to the curriculum

- It must pave the way to provide multi-sensory experience to the students.

- Assess whether the student finds difficulty in understanding and mastering the content through classical approach.

- Ensure the topic is difficult to be explained through chalk and talk method.

- Ensure the topic which may require virtual reality

- Ensure the process pertaining to the content are to be witnessed by the students and not allowing them to assume. Learners construct new knowledge and modify existing knowledge as they experience situations, problems, circumstances, and other events in learning settings [11].

\section{DESIGNING OF E-CONTENT}

In the present study, the investigator decided to develop the e-content in HTML format based on the objectives. At this stage, the sub topics were formed and appropriate images, animations, and videos were collected.

\section{SCRIPT WRITING FOR VIDEO}

The script was carefully planned and prepared adhering to the norms. The audio part of the script contains the matter that has to be orally explained and the sound effect. The 'visual' part of the script shows all shot that will explain the processes involved in the selected topic.

\section{STORY BOARD FOR VIDEO}

Story board is a script with visuals and explanations which actualizes the development of e-content. The investigator used three column format for story board writing. In this format the first column contains content part, second one was the visuals, and the third one was the effect of e-content.

\section{EDITING}

Editing was done by the investigators with the help of experts in the studio. The video coverage of the topic "cloning was done by the programmer. The e-content in HTML format, contains text, images, video and animations. The investigator prepared the video and animation to explain the concept according to the instructional objectives and carefully edited. The investigator used Adobe premiere software for video editing. After the editing the total video portion is presented as a complete e-content which was validated by the experts. A rubric was developed to ascertain the following information from the students.

- Does the introduction of the e-content in science developed by the investigator provide relevant information?

- Does the content include all important points?

- Are the text elements difficult to understand?

- Is the delivery well-rehearsed?

- Are the components of Multimedia used appropriately?

- Are the components of Multimedia used effectively?

- Does the use of technology effectively impart scientific knowledge?

\section{RESUlTS AND DISCUSSION}

TABLE I: SHOWING MEAN SCORES OF CONTROL GROUP AND

\begin{tabular}{|c|c|c|c|c|c|}
\hline \multicolumn{6}{|c|}{ EXPERIMENTAL GROUP IN THE PRE-TEST } \\
\hline Group & $N$ & Mean & SD & $\begin{array}{c}\text { 't' } \\
\text { value }\end{array}$ & Sig \\
\hline $\begin{array}{l}\text { Control } \\
\text { group }\end{array}$ & 30 & 7.47 & 1.14 & \multirow{2}{*}{1.197} & \multirow{2}{*}{$\begin{array}{c}\text { Not } \\
\text { Significant at } \\
0.01 \text { level }\end{array}$} \\
\hline $\begin{array}{l}\text { Experimental } \\
\text { group }\end{array}$ & 30 & 7.80 & 1.24 & & \\
\hline
\end{tabular}


TABLE II: SHOWING MEAN SCORES OF CONTROL GROUP AND EXPERIMENTAL GROUP IN THE POST-TEST

\begin{tabular}{|c|l|l|l|c|c|}
\hline Group & $N$ & Mean & SD & $\begin{array}{c}\text { ' } t \text { ' } \\
\text { value }\end{array}$ & Sig \\
\hline Control group & 30 & 8.77 & 1.16 & & \\
\hline $\begin{array}{c}\text { Experimental } \\
\text { group }\end{array}$ & 30 & 12.57 & 0.77 & 15.2 & $\begin{array}{c}\text { Significant at } 0.01 \\
\text { level }\end{array}$ \\
\hline
\end{tabular}

TABLE III: SHOWING MEAN SCORES OF CONTROL GROUP AND

EXPERIMENTAL GROUP IN THE POST-TEST BASED ON GENDER

\begin{tabular}{|c|c|c|c|c|c|}
\hline Gender & $N$ & Mean & SD & ' $t$ ' value & Sig \\
\hline Male & 26 & 10.62 & 2.48 & \multirow{2}{*}{0.799} & $\begin{array}{c}\text { Not Significant at } \\
0.01 \text { level }\end{array}$ \\
\cline { 1 - 3 } Female & 34 & 10.76 & 1.88 & & \\
\hline
\end{tabular}

It can be found from the Table I that students in both control and experimental group do not differ in their pre-test performance which shows equivalence of both the groups in their entry behavior as far as their performance in science learning was concerned. It is heartening to note that the experimental group which was given treatment on e-content along with classroom discussion outperformed their counterparts as per Table II. From these two results it is inferred that e-content integration into science learning was found effective. In fact these findings have quantum of agreement with Amutha's study. It is imperative to take cognizance in the research study that the e-content integration into science learning did make no gender difference as per Table III. Indeed it is good to note the e-content integration was found effective with the science of learning of boys and girls in terms of providing equity pedagogy.

Responses of the students through rubrics are as follows.

The introduction part of the module was able to win the confidence of the students. Their response reveals that introduction provides relevant information and establishes a clear purpose of engaging the listener.

Script for cloning is well planned. The story board is well written. Language is very simple and precise.

As many as twenty six out of thirty students revealed that the e-content presents accurate information and concise concepts. Four of the students identified creativity and originality in the development of e-content. It is heartening to note that all the students felt that the whole e-content is easy to read with appropriate use of font size, bullets, italics and bold for headings and subheadings.

All the students felt that delivery by the investigator in the e-content is well rehearsed and smooth.

Use of multimedia in the content evoked good feedback from the students. All the students revealed that the photographs, graphics, audio and video were appropriate and created interest.

Forty percent of the students came out with additional remarks that the graphics and animation were relevant to the audio and reinforce the content.
The entire shooting took place in the studio, in a quiet environment without background noise and distractions.

\section{RECOMMENDATIONS}

The following recommendations are given based on the findings and conclusions

- Teachers may be trained to develop e-contents of their own.

- Developed e-content may be distributed to teachers and students from educational institution for supplementing and complementing the process of teaching and learning in higher education.

- Laboratory demonstration like dissection of plants and animals may be taught through multimedia so that no animal or plant has to sacrifice its life.

\section{CONCLUSION}

Learning through e-content encourages critical and active learning. With e-content materials, the learner and teacher will understand that he or she is changing from a provider of facts to the one who facilitates a learning environment [12]. It is in this assumption that this investigation attempts to devise an innovative teaching technique through e-content approach. Humans can integrate information from different sensory stimuli into meaningful experiences. This empirical study proved that e-content enhance the achievement of the students at tertiary level.

\section{REFERENCES}

[1] K. E. Ayse and B. Giray. The effect of guided-inquiry instruction on 6th grade Turkish students' achievement, science process skills, and attitudes toward science. International Journal of Science Education. [Online]. Available: http://www.ingentaconnect.com/content/routledg/tsed/2014/0000003 6/00000001/art00004

[2] N. Sabelli, "Complexity, technology, science and education," Journal of the Learning Sciences, vol. 15, pp. 5-10, 2006.

[3] Vision and change: A call to action in undergraduate biology education, Final Report of the National Conference Organized by American Association for the Advancement of Science. Washington, DC., 2011

[4] NZCER Annual Report 2013-2014. [Online]. Available: http://www.nzcer.org.nz/system/files/Annual\%20Report\%2013-14.pd f.

[5] S. P. Gluckman, "KNZM FRS FRSNZ looking ahead: Science education for the Twenty First Century," A report from the Prime Minister's Chief Science Advisor, 2011.

[6] H. W. Lee, K. Y. Lim, and B. Grabowski, "Generative learning strategies and metacognitive feedback to facilitate comprehension of complex science topics and self-regulation," Journal of Educational Multimedia and Hypermedia, vol.18, no. 1, pp. 5-25, 2009.

[7] C. E. Hmelo-Silver and R. Azevedo, "Understanding complex systems: Some core challenges," Journal of the Learning Sciences, vol. 15, no. 1, pp. 53-61, 2006.

[8] S. Amutha, "Empowerment of science teaching competence of B.Ed trainees in the rural areas through e-content with a metacognitive instructional design," Ph.D Dissertation, Department of Educational Technology, Bharathidasan University, India, 2010.

[9] S. Emanuel. (2010). Integration of Information Technology in Teaching Learning Process. [Online]. Available: http://www.educationinindia.net/download/ Shamsha-emanuel.pdf

[10] S. B. Benjamin, Taxonomy of Educational Objectives, Boston, MA Allyn and Bacon, 1956.

[11] J.-Y. Tzeng and T. M. Schwen, "Mental representation-based task analysis for analyzing value-laden performance," Educational Technology Research and Development, vol. 51, no. 3, pp. 5-21, 2003. 
[12] B. C. Buckley and C. J. Boulter, "Analysis of representations in model-based teaching and learning in science," in R. Paton et al., (eds.), Visual Representations and Interpretations, Springer.

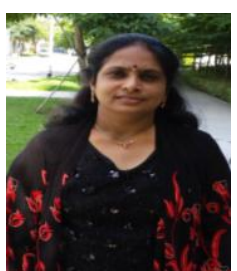

S. Amutha is an Indian working as an assistant professor in the Department of Educational Technology Bharathidasan University, Tiruchirappalli. Her areas of specialization are educational psychology, educational technology, educational research, e-content development and cognitive science. She has published 15 International and 14 National research papers in Journals and 11 in edited books. She is the recipient of Dr. Aruna Rajagopal Science Award given by Thanjavur Tamil University, India. She serves as the reviewer of journals like British Journal of Educational Technology (BJET) United Kingdom, American International Journal of Research in Humanities, Arts and Social Sciences (AIJRHASS) United States, Reflections des ERA Journal of Education, Dr.MGR Educational and Research Institute University, Chennai and International Journal of Management and Development Studies (IJMDS) (Online). She has authored books on Career Education and Philosophy of Education. She is the research supervisor for M.Ed, M.Phil and Ph.D programmes in education. She acted as a resource person for many faculty development programmes and e-content development workshops. Also she visited countries like China, Srilanka, Malaysia and Singapore. 